\title{
ОБЩЕСТВЕННЫЕ И КОНСУЛЬТАТИВНЫЕ СОВЕТЫ ПРИ ОРГАНАХ ПУБЛИЧНОЙ ВЛАСТИ КАК ВИД ГРУППЫ ИНТЕРЕСОВ
}

\author{
Ю. А. Перельштейн \\ Воронежский государственный университет \\ Поступила в редакцию 8 сентября 2020 г.
}

\begin{abstract}
Аннотация: статья посвящена исследованию политико-правовой теории группы интересов, механизмам взаимодействия групп интересов с государствол. Расслатривается механизм реализаиии теории группь интересов в России. Дается характеристика общественно-консультативньлм органал как вида группы интересов.
\end{abstract}

Ключевые слова: группы интересов, плюрализл, корпоративизл, общественные органы, консультативные органы.

\begin{abstract}
: the article is devoted to the study of the theory of interest groups, mechanisms of interaction of interest groups with the state. The mechanism of implementation of the theory of interest groups in Russia is considered. The article describes public Advisory bodies as a type of interest group.
\end{abstract}

Key words: interest groups, pluralism, corporatism, public bodies, Advisory bodies.

В демократическом государстве особое значение имеет то, каким образом интересы граждан представляются в органах публичной власти. Граждане могут выражать свое мнение как лично, так и коллективно, в том числе через различные негосударственные структуры (общественные объединения и т. д.).

В науке сложилось несколько подходов к исследованию процесса влияния мнения граждан на осуществляемую политику государства. Одним из них является теория группы интересов. Основой данной теории послужили работы английских философров XIX в. - начала XX в., в то время была выдвинута и обоснована идея о том, что именно группа является базовой единицей общества ${ }^{1}$. В дальнейшем это положение легло в основу идеи А. Бентли о том, что общественная жизнь не сводится к деятельности официальных институтов власти, которые принимают решения на основе своих полномочий. Анализ конституционного устройства власти не позволяет понять, почему принимаются те или иные решения и кто действительно контролирует деятельность власти. Реальность оказывается намного сложнее и динамичнее, она пронизана противоречивым взаимодействием предпочтений, установок, стереотипов поведения ее участников. В основе подхода А. Бентли к изучению государственного

${ }^{1}$ См.: Голдовский А. П. Зарождение теории формирования системы представительства интересов групп давления // Экономические науки. 2009. № 8. С. 63.

(C) Перельштейн Ю. А., 2021. 
управления лежит понятие деятельности людей, которая обусловлена их интересами и направлена на их реализацию. Своих целей люди достигают не индивидуально, а через группы, в которые объединяются на основе общности интересов. Таким образом, политика представляет собой взаимодействие заинтересованных групп, преследующих свои цели, а общество - это совокупность различных групп интересов ${ }^{2}$.

Продолжил развитие теории группы интересов политолог Д. Трумэн. В своей работе «Управленческий процесс» он указывал, что политика это процесс групповой конкуренции за власть над распределением ресурсов. Человек представляет собой существо социальное, поэтому люди всегда оказываются в какой-то зависимости друг от друга, что приводит их объединение в группы и сообщества. Д. Трумэн полагал, что группы интересов - это группы, состоящие из людей, руководствующихся определенными интересами и взглядами, с целью оказания влияния на другие социальные группы. Группы, которые пользуются для достижения своих целей помощью правительственных организаций, являются политическими группами интересов ${ }^{3}$.

Таким образом, под группой интересов можно понимать добровольное объединение граждан, формирующееся с целью выражения и отстаивания политически значимых интересов в отношениях с государством и другими политическими институтами. Можно сказать, что такая группа - это один из способов влияния гражданского общества на решения, которые принимаются органами государственной власти и органами местного самоуправления. Основное отличие группы интересов от политической партии заключается в том, что она не участвует в политической борьбе за власть, а всего лишь отстаивает свои интересы во взаимоотношениях с государством.

Теория группы интересов дала толчок к развитию моделей взаимодействия группы и государства: корпоративной и плюралистической.

Корпоративизм предполагает такую организацию политической жизни, при которой отношения между группами интересов и государством реализуются через объединения фризических и юридических лиц, т. е. корпорации 4 . Граждане могут влиять на решения, принимаемые государством, посредством членства в корпоративных организациях, например общественных организациях, профессиональных союзах, союзах работодателей и т. д. Являясь частью гражданского общества, эти структуры добиваются своих целей не в рамках публичной политики, как политические партии, а путем прямого воздействия на государственные институты. В корпоративной государственно-политической системе важнейшими аспектами публичной политики являются консультации правительства с организованными группами интересов, например с проф-

${ }^{2}$ См.: Там же.

${ }^{3}$ См.: Макаренко В. Л. Групповые интересы и властно-управленческий аппарат : к методологии исследования. URL: http://ecsocma№.hse.ru/data/666/943/ 1231/17_Makare№ko.pdf (дата обращения: 05.05.2020).

${ }^{4}$ См.: Голдовский А. П. Указ. соч. С. 64. 


\section{Вестник ВГУ. Серия: Право}

союзами и бизнес-ассоциациями ${ }^{5}$. При корпоративисткой форме взаимодействия прослеживается зависимость групп интересов от финансовых и административных ресурсов государства и влияние органов власти на их состав и фуннционирование ${ }^{6}$.

После Второй мировой войны корпоративистская модель представления интересов группы активно стала развиваться в таких странах, как Бельгия, Дания, Швеция, Норвегия. В этих государствах в политике большую роль играли социал-демократические партии, что повлекло следующее: включение групп интересов в процесс принятия решений государством; создание социальных пактов, гарантировавших мирное развитие трудовых отношений и превращение профсоюзов, предпринимателей и правительственных институтов в социальных партнеров; dopмирование новой промышленной политики, предполагавшей обязательные консультации по важнейшим вопросам с представителями бизнеса и профсоюзов; проведение новой политики в области социальной защиты и образования; привлечение групп интересов к процессам экономического и социального реформирования ${ }^{7}$.

Плюрализм предполагает, что политическая система состоит из конкурирующих друг с другом организованных групп интересов и строится на их постоянной конфронтации. Высокий уровень демократичности государства характеризуется наличием большого числа групп интересов, которые функционируют на основе свободной конкуренции. Поскольку каждая группа преследует свои цели, то они стремятся достигнуть некого баланса во взаимодействии друг с другом. В такой ситуации государство представляет собой независимого посредника, который отражает в своих решениях достигнутый баланс интересов различных групп. Эти решения отражают разнообразие мнений и общественных потребностей, становят-

- ся результатом компромиссов противостоящих групп. Е. Латам отмечал, что каждый нормативный документ представляет собой некий компромисс, поскольку разрешение межгрупповых конфликтов - это процесс обсуждения и поиска согласия 8 .

Наиболее последовательно идеалы плюралистического взаимодействия были реализованы в США. В настоящее время в США существует

${ }^{5}$ См.: Половнева Л. С. Теоретико-концептуальные подходы к анализу взаимодействия групп интересов и государства в политическом процессе // Научные ведомости Белгородского гос. ун-та. Серия: История. Политология. 2016. № 37. С. 151.

6 См.: Тарасенко А. В. Региональные консультативные органы как канал артикуляции общественных интересов в современной России : авторедр. дис. ... канд. полит. наук. URL: https://www.dissercat.com/co№teNot/regio№al№yeko№sultativ№ye-orga№y-kak-ka№al-artikulyatsii-obshchestve№№ykh-i№teresovv-sovre/read) (дата обращения: 12.05.2020).

${ }^{7}$ См.: Шапкин И. Н. Корпоративизм или плюрализм? Институциональные модели взаимодействия современного государства и общества // Век глобализации. 2018. № 1. С. 24.

${ }^{8}$ См.: Там же. С. 35. 
большое число различных групп и объединений по интересам. Исходя из количества участников, объема экономических и организационных ресурсов и степени влияния к ведущим заинтересованным группам можно отнести крупные бизнес-ассоциации и предпринимательские группы, общенациональные профессиональные группы и фермерские объединения, а к менее влиятельным - религиозные и идеологические объединения, спортивные ассоциации и т. д. ${ }^{9}$

В современных российских реалиях возникает вопрос - находит ли в нашей стране свое выражение теория группы интересов и на основе какой модели взаимодействует группа интересов с государством - на основе корпоративизма или плюрализма?

Интересы различных категорий граждан, к примеру, могут выражаться: общественными объединениями, которые создаются гражданами на основе общности интересов для реализации общих целей ${ }^{10}$; профрсююзами - объединениями граждан, связанных общими производственными, профессиональными интересами по роду их деятельности, создаваемыми в целях представительства и защиты их социально-трудовых прав и интересов ${ }^{11}$; объединениями работодателей, которые создаются для защиты своих прав и охраняемых законом интересов ${ }^{12}$. Необходимо отметить, что в законодательной дефиниции данных организаций имеются такие конструкции, как «представление интересов, общность интересов». В российском законодательстве термин «группа интересов» не используется, что можно объяснить особенностями русского языка и особенностями перевода с английских источников. Термин «interest group» может переводиться как группа по интересам, группа интересов, в русском языке более привычно использовать формулировку «интересы группы».

Федеральный закон от 21 июля 2014 г. № 212-ФЗ «Об основах общественного контроля в Российской Федерации» предусмотрел возможность создания при федеральных органах исполнительной власти, при законодательных (представительных) и исполнительных органах государственной власти субъектов РФ общественных советов, которые при органах власти выполняют консультативно-совещательные функции и участвуют в осуществлении общественного контроля в порядке и формах, предусмотренных законодательством ${ }^{13}$.

В положениях о данных советах говорится, что их деятельность призвана обеспечить учет потребностей и интересов граждан Российской Фе-

${ }^{9}$ См.: Шапкин И. Н. Указ. соч. С. 286.

${ }^{10}$ Об общественных объединениях : федер. закон от 19 мая 1995 г. № 82-ФЗ. Доступ из справ.-правовой системы «КонсультантПлюс».

${ }^{11} \mathrm{O}$ профессиональных союзах, их правах и гарантиях деятельности : федер. закон от 12 января 1996 г. № 10-ФЗ. Доступ из справ.-правовой системы «КонсультантПлюс».

${ }^{12}$ Об объединениях работодателей : федер. закон от 27 ноября 2002 г. № 156Ф3. Доступ из справ.-правовой системы «КонсультантПлюс».

${ }^{13}$ Об основах общественного контроля в Российской Федерации : федер. закон от 21 июля 2014 г. № 212-ФЗ. Доступ из справ.-правовой системы «КонсультантПлюс». 
дерации. В нормативных актах напрямую не указано, что общественные советы создаются по социальному признаку, однако проведенные исследования персонального состава общественных консультативных органов позволяют сделать вывод, что прослеживается определенная корпоративность их членов, принадлежность к определенной социальной группе. Например, в общественный совет при департаменте физической культуры и спорта Воронежской области входят представители спортивной сферы - тренеры, преподаватели физической культуры в школе и вузах, спортсмены, представители организаций, осуществляющих поддержку физической культуры и спорта; в состав общественного совета при департаменте аграрной политики входят работники сферы агропромышленного комплекса; в состав общественного совета при управлении по охране объектов культурного наследия Воронежской области входят работники сферы культуры и искусств, а также представители общественных организаций, занимающихся охраной культурного наследия ${ }^{14}$.

Федеральный закон от 30 апреля 1999 г. № 82-ФЗ «О гарантиях прав коренных малочисленных народов Российской Федерации» предусмотрел возможность создания советов представителей малочисленных народов при органах исполнительной власти субъектов РФ и органах местного самоуправления. Советы при органах власти субъектов РФ создаются на общественных началах в целях защиты прав, свобод и законных интересов малочисленных народов, содействия их социально-экономическому, культурному развитию, а также реализации государственной национальной политики. Советы малочисленных народов при органах местного самоуправления в местах традиционного проживания и традиционной хозяйственной деятельности создаются в целях содействия в принятии решений, касающихся традиционного образа жизни и освоения территорий традиционного пользования коренных малочисленных народов ${ }^{15}$.

В соответствии с Федеральным законом от 17 июня 1996 г. № 74-Ф3 «О национально-культурной автономии» при уполномоченном федеральном органе исполнительной власти создается консультативный совет по делам национально-культурных автономий, а при органах исполнительной власти субъектов РФ и органах местного самоуправления могут создаваться консультативные советы или иные совещательные органы по делам национально-культурных автономий ${ }^{16}$. Во исполнение данного положения при Федеральном агентстве по делам национальностей был создан Консультативный совет по делам национально-культурных автономий; на уровне субъектов, например в Воронежской области, действует Национальная палата при губернаторе Воронежской области.

${ }^{14}$ См.: Сайт Общественной палаты Воронежской области. URL: http://opvo36. ru/ (дата обращения: 20.06.2020).

${ }^{15}$ См.: Перельштейн Ю. А. Представительство национальных меньшинств в органах публичной власти // Теория народного представительства : научное наследие профессора В. С. Основина и современность : материалы Междунар. науч.-практ. конф. (Воронеж, 29 марта 2018 г.). Воронеж, 2018. С. 169.

16 Доступ из справ.-правовой системы «КонсультантПлюс». 
Законодательство отдельных субъектов России предусматривает возможность создания общественных органов молодежи. Например, Закон г. Москвы от 30 сентября 2009 г. № 39 «О молодежи» закрепляет, что молодежный совещательно-консультативный орган - коллегиальный орган, состоящий из молодых граждан, созданный органами государственной власти г. Москвы, органами местного самоуправления внутригородских муниципальных образований в г. Москве или организацией для участия молодежи в разработке и принятии управленческих решений ${ }^{17}$. Во исполнение данного положения создана Молодежная палата при Московской городской Думе, которая состоит из представителей молодежи Москвы и является молодежным совещательно-консультативным органом для обсуждения проектов законов г. Москвы, проектов постановлений Московской городской Думы в области реализации и защиты прав, свобод и законных интересов молодежи ${ }^{18}$.

В отдельных субъектах РФ создаются консультативные советы по делам ветеранов и инвалидов. В состав таких органов входят представители общественных объединений по делам ветеранов и инвалидов, которые способствуют информированию органов власти о потребностях данной категории граждан ${ }^{19}$.

Можно сказать, что общественные и консультативные советы при органах государственной власти осуществляют представление определенной социальной группы. Они способствуют налаживанию и ведению диалога между обществом и государством ${ }^{20}$. Стоит отметить отличие в персональном составе данных членов: в общественный совет входят представители определенной социальной группы, в консультативные советы помимо представителей социальных групп входят представители органа публичной власти.

Следующий вопрос связан с моделью представления интересов группы консультативными органами. По нашему мнению, они представляют интересы в соответствии с корпоративной моделью. Как уже отмечалось,

17 Доступ из справ.-правовой системы «КонсультантПлюс».

18 О Молодежной палате (Молодежном парламенте) при Московской городской Думе : постановление Московской городской Думы от 27 сентября 2006 г. № 265. Доступ из справ.-правовой системы «КонсультантПлюс».

${ }^{19}$ О Совете по делам инвалидов при Главе Республики Карелия : указ Главы РК от 21 марта 2003 г. № 67 ; О Совете по делам инвалидов и ветеранов при Президенте Карачаево-Черкесской Республики : указ Президента Карачаево-Черкесской Республики от 11 августа 2009 г. № 133 ; О координационном совете по делам инвалидов при правительстве Ленинградской области : распоряжение губернатора Ленинградской области от 7 ноября 2013 г. № 808-рг. Доступ из справ.-правовой системы «КонсультантПлюс».

${ }^{20}$ См.: Сазонникова E. B. Диалог как форма и организация общения : конституционно-правовой аспект // Научные труды. Российская академия юридических наук. М., 2016. Вып. 16, т. 1. С. 316 ; Ее же. О теме диалога в науке конституционного права // Человек в глобальном мире : материалы Междунар. науч. конф. / под ред. Н. В. Бутусовой, Й. Ананиева. Воронеж, 2015. С. 186. 


\section{Вестник ВГУ. Серия: Право}

в рамках корпоративизма в формировании группы интересов участвует государство. Отметим следующее:

1) в формировании общественных и консультативных советов большую роль играет орган публичной власти. Например, требования к кандидатам в состав общественного совета при федеральном органе исполнительной власти разрабатываются соответствующим фредеральным органом исполнительной власти совместно с Общественной палатой Российской Федерации. Персональный состав конкретного общественного совета утверждается приказом соответствующего органа власти ${ }^{21}$. В состав консультативного совета всегда входят представители от органа публичной власти;

2) организационно-техническое обеспечение деятельности общественных и консультативных советов осуществляется органами власти. Уровень материально-технического обеспечения может быть разным - от полного обеспечения до оказания содействия в данной деятельности.

Данные положения подтверждают, что общественные и консультативные советы используют корпоративную модель представления интересов группы.

Итак, группа интересов представляет собой добровольное объединение граждан, формирующееся с целью выражения и отстаивания интересов в отношениях с государством и другими политическими институтами. В отличие от политической партии она не участвует в борьбе за власть, а лишь отстаивает свои интересы во взаимоотношениях с государством.

Представление интересов граждан Российской Федерации группа интересов может осуществлять такими структурами, как: общественные объединения, в том числе профсоюзы; объединения работодателей; общественные советы при органах государственной власти и местного са-

- моуправления. В законодательстве термин «группа интересов» не встречается, но используются такие конструкции, как «интересы группы», «общность интересов».

Представление интересов определенной группы осуществляется общественными и консультативными советами, которые позволяют учитывать мнения граждан при реализации государственной политики.

${ }^{21} \mathrm{O}$ порядке образования общественных советов при фредеральных министерствах, федеральных службах и федеральных агентствах, руководство деятельностью которых осуществляет Президент Российской Федерации, при федеральных службах и федеральных агентствах, подведомственных этим федеральным министерствам : указ Президента РФ от 4 августа 2006 г. № 842 ; О порядке образования общественных советов при федеральных министерствах, руководство которыми осуществляет Правительство Российской Федерации, фредеральных службах и федеральных агентствах, подведомственных этим федеральным министерствам, а также федеральных службах и федеральных агентствах, руководство которыми осуществляет Правительство Российской Федерации : постановление Правительства РФ от 2 августа 2005 г. № 481. Доступ из справ.-правовой системы «КонсультантПлюс». 
Государственная власть. Законодательный процесс...

Общественный и консультативные советы - это канал связи между государством и группой.

Общественные и консультативные советы основаны на корпоративной модели представления интересов группы. Они фрормируются на основе нормативного правового акта, который принимается соответствующим органом публичной власти; на органы публичной власти возложено и материально-техническое обеспечение их деятельности.

Воронежский государственный университет

Перельштейн Ю. А., аспирант кафбедры конституиионного и муниципального права

E-mail: julie23_94@mail.ru
Voronezh State University

Perelshtein Yu. A., Post-graduate Student of the Constitutional and Municipal Law Department

E-mail:julie23_94@mail.ru 